\title{
Connecting social forestry to conservation policies in Tanah Papua
}

\author{
Sepus M. Fatem ${ }^{1,2^{*}}$ \\ 1 Forestry Faculty of Universitas Papua. Jl. Gunung Salju Amban Manokwari, Papua Barat \\ 2 Doctoral Student at Forestry Faculty of Universitas Gadjah Mada, Jogjakarta \\ * Corresponding author: sepus_fatem@yahoo.com
}

\begin{abstract}
Papua is the region with the largest remaining forest resources in Indonesia. This amounts to $42,224,840$ hectares of forest areas, which in other words means that $95 \%$ of its total area is listed as forests. The breadth of forest coverage is formalized by Forestry Ministerial Decree of Indonesia no. 891/Kpts-II/1999 on the Designation of Provincial Forest Area and Inland Waters in Tanah Papua. Meanwhile, forest resources plays an important part of people's lives in Tanah Papua and holds an important function among customary communities in Papua. Nevertheless, as yet there has been no meaningful social forestry program that provides direct benefits to communities. As a response to the special autonomy of Papua, several initiatives aimed at providing formal access and support services to local people in forest resource management. Ironically however, such initiatives are discouraged by the central government, arguing that they should originate from the Ministry of Environment and Forestry. Despite these circumstances, Tambrauw and West Papua have declared themselves to be a conservation district and conservation province, respectively. This article attempts to briefly portray the dynamics of these conservation initiatives and the possibilities of developing synergy with social forestry programming in Tambrauw District and West Papua Province.
\end{abstract}

Keywords: Forest policy; Social Forestry; conservation policies; Tambrauw; West Papua

\section{Introduction}

Social forestry refers to a diverse list of arrangement, including industrial, conventional, and other forestry initiatives modified to enable profit distribution to local communities (Gilmour and Fisher, 1991). Therefore, the most important element in the development of social forestry is the involvement of forest-dependent communities to gain benefit from forest resources. The concept of social forestry - as a way to grant legal access to local communities to utilize forest resources has been recognized since the 1990s. Before this time, for forest administrators in particular, those living around forest zones were merely perceived as menial labor, having limited contribution to forest management. During the period of 1990-1998, there was a growing awareness that customary communities played an important role in forest resource management.

Based on data in Indonesia, the area of farm forestry in Indonesia covers 1,265,460 hectares (Suryandari and Puspitojati, 2003), and until 2006, community forestry covered a small area of 33,576 hectares (Ditjen Rehabilitasi Lahan dan Perhutanan Sosial, 2006). The coverage area significantly increased in 2015, to which the total area officially designated amounted to 2,1 million hectares. In 2006, the area for National Program for Forest and Land Rehabilitation amounted to 551,739 hectares comprising 618,261 hectares for reforestation, 5,602 hectares for farm forestry, and 4,963 hectares for urban forestry (Ditjen Rehabilitasi Lahan dan Perhutanan Sosial, 2006). These statistics indicate that the government began to make a significant effort in the management supporting the social forestry model. In the period of 2007-2014, the government attempted to issue several regulations providing the opportunity for local people to participate in forest management.

The development of a social forestry model in Indonesia faces continuing challenges. Both forest managers and local communities also continue to point fingers about the extent of their 
role in the schemes that are being developed, indicating a continued fight for rights to forest resources. During the period of 2000-2007, the Community Forest Program, which was previously aimed to reduce illegal logging, ironically created new conflicts, in some cases exacerbating the problem. Conflicts emerged in several ways, including in the areas of joint management arrangements, licensing issues, procedural inconsistency, and the overall contestation around the responsibility of forest resource provision to and among communities (Suharman, 2004). Problems related to community forest management include the acknowledgement of management access solely to the landowner, technical issues in the application of reforestation objectives, and forest maintenance inconsistencies, as well as challenges involving forest resource exploitation among communities (Sukadaryati, 2006). Between 2007-2014, the phase 1 of social forestry policy also faced issues of growing sentiments making claims to more fundamental agrarian reform (Awang, 2010).

Although much is written about the progress and development of social forestry in Indonesia (Maryudi et al., 2012; Sahide et al., 2018; Fisher et al., 2018). Tanah Papua presents a unique set of challenges. Furthermore, although Tanah Papua has the largest area of forest resources in Indonesia, research on and about the region is severely lacking. In this paper, I will highlight how social forestry connects with the broader movement taking place in Tanah Papua to conserve forest resources, particularly related to the dynamics unfolding in Tambrauw District and West Papua Province.

\section{Tanah Papua_traditional_region: Possibility and access for Social forestry}

Tanah Papua has drawn global attention due to its rich biodiversity and diverse culture. There are 316 ethnic groups divided based on customary laws of the people (Patay and Sasmitawidjaya, 2005; Mampioper and Ayomi, 2008). There are 7 main customary areas. First is Mamta covering Port Numbay, Sentani, Genyem, Depapre, Demta, Sarmi, Bonggo, Mamberamo. The second is Saireri covering Biak Numfor, Supiori, Yapen, Waropen, the coastal area of Nabire. The third is Domberay covering Manokwari, Bintuni, Babo, Wondama, Sorong, Raja Ampat, Teminabuan, Inawantan, Ayamaru, Aifat, Aitinyo. The fourth is Bomberai covering Fakfak, Kaimana, Kokonao and Mimika. The fifth is Ha Anim covering Merauke, Digoel, Muyu, Asmat and Mandobo. The sixth is Me Pago, covering the Bintang mountainous area, which includes Wamena, Tiom, Kurima, Oksibil, Okbibab. Finally, the seventh is La Pago covering Puncak Jaya, Tolikara, Paniai, inland Nabire (Mampioper and Ayomi, 2008). The topography of each customary area and the origins of the groups have formed specific characteristics in managing their forest, natural, and cultural resources. Their management systems are based on local and traditional knowledge of each ethnic group. "Talking about the forest in Papua necessarily means talking about the people of Papua and their culture". Therefore, there is no single social forestry scheme that can meet all cultural needs and physical characteristics of the diverse customary communities in Papua. This article is an effort at highlighting the dynamics of social forestry programming and how it might fit into the overall policy of establishing Tambrauw as a conservation district and at a larger scale, West Papua as a conservation province.

The shift in forest policy in Indonesia, from large-scale timber-based management to a community-based approach, points to the potential opportunity for engaging with customary communities on their terms in Papua. This timely policy change allows for more adequately improving livelihoods of indigenous communities, especially forest-dependent people. The increasing concern of protecting indigenous people's rights should also be necessarily concerned with the broader policies on the environment where these people live, as well as the cultural norms and values that shape forest management considerations. The values and norms are in fact shaped by their interactions with the environment (Wanggai, 1999; Berkes et al., 2000; Berkes 2001). 
Community-based forest management is believed to be a reasonable policy approach in forest management. The reasons are that this type of management does not only position local communities as actors in forest management but also goes against the common stereotype that the state knows better than forest-dependent people how to manage forests (Awang, 1999). The facts reflect that, in several regions in Indonesia, forest management is enhanced when local community are directly involved in programming initiatives (Awang, 1999). One example is forest management carried out in a natural sanctuary in the Arfak mountains, Papua. The classification of sanctuary areas is based on local knowledge, namely, bahamti, nimahamti, and susti. Bahamti refers to the primary forest zone located higher than settlement area. People are forbidden to build house or garden in this area. However, they are still allowed to cut small size of trees, ropes, and tree barks for house construction. While, Nimahamti refers to forest zone characterized by mosses growing on trees. This zone is geographically difficult to reach. With cold temperature, some plants, especially agricultural plants cannot grow in this zone. Susti refers to the secondary forest zone people can use for farming or collecting woods for daily uses. It is used for shifting cultivation practices commonly with a duration of 2-3 years. This zone of farmland is characterized by forest stands which are $40 \mathrm{~cm}$ in diameter and trees with 7-8 meters in height (Laksono, 2005).

The problems of forest management in Indonesia in the last few decades have come from relations between the state and socio-cultural authority, particularly in relation to livelihoods and economic opportunity among customary peoples. Challenges to forest management approaches in Indonesia has triggered new discourses and debates about land rights, particularly after the petition of Aliansi Masyarakat Adat Nusantara (the Alliance of Indigenous People, AMAN) challenged the status and recognition of customary forests. The legal consideration in the decision of the Constitutional Court of the Republic of Indonesia No. 34/PUUIX/2011 states that Article 4 Section 3 of the Forestry Law contradicts the 1945 Constitution, making it conditionally unconstitutional. It says that forest control by the state has to recognize, protect, respect, and fulfill the rights of customary communities as long as they are in line with the existing laws and not in conflict with national interests. This is relevant across Indonesia, but has particular implications for Tanah Papua.

As a part of President Joko Widodo's administration, the "Nawacita" policy document that lays out presidential priorities, the Ministry of Environment and Forestry (MOEF) has targeted 12.7 million hectares for allocation as social forestry areas. These areas cover a diverse set of categories including customary forests, forestry partnerships, community forestry, village forests, and a variety of other schemes. As a supporting policy, MOEF issued ministerial regulation No. P.32 of 2015 concerning Private Forest and No. P.83 of 2016 concerning Social Forestry.

The sustainability of forest resource management in Papua depends heavily on how customary rights are recognized and accommodated in planning, implementation, and evaluation processes. Social forestry, as a policy, is therefore instrumental to ensuring that forest resource management is beneficial and sustainable for customary communities throughout the region. Customary land recognition is one potential opportunity for Tanah Papua. In the case of Tanah Papua, social forestry schemes aim to provide economic advantages for forest-dependent people while also helping to preserve their forests. However, until 2017 there had as yet been no social forestry scheme introduced.

There are 3 reasons why the implementation of customary forest schemes in Papua are a challenge to implement. First is a lack of collaborative efforts of multidisciplinary teams in addressing the matter. Second is the insufficient understanding of the problem among policy makers. And third, is the reluctance among bureaucrats for power sharing arrangements with customary communities.

The author was involved in some activities providing assistance and advocacy in the area of forestry policy in Tanah Papua. From my experiences being actively involved in such policymaking discussions, I believe that there is a lack of commitment to collaborative efforts in forest 
management. Government bureaucrats in charge of forest-related administration, academics, and social activists do not really engage in a productive exchange of ideas or concepts. Consequently, social forestry policy in Tanah Papua is not well adopted and difficult to implement due to the challenges in accessing the field sites. Another serious challenge is the strong domination of the central government as part of their overwhelming focus on normative policies. State-made policies often do not take local knowledge into account, even though local experiences are shaped by generations of sustainable traditional practices on managing forest resources. Therefore, the notion of special autonomy as it has been conferred to Tanah Papua seems to only be halfheartedly granted by the central government. Every local initiative to empower indigenous people of Tanah Papua, including those related to forest resources, often faces negative responses from the central government.

Given this background on social forestry and special autonomy in Tanah Papua, as well as my involvement in these policy discussions, I offer several examples of opportunities for addressing some key barriers and creating a new path forward. First, prior to the implementation of social forestry programs initiated by the central government, local governments in Tanah Papua and several non-governmental organizations in the region had already encouraged indigenous communities to claim customary rights for access to forest management. The strategy sought to develop a collaborative effort in formulating norms, standards, procedures, and criteria for community-based forest management. The subsequent step included the issuance of 18 licenses for customary communities to exploit timber forest products (IUPHHK-MHA) on 78,000 hectares of forest zones. However, these licenses were not granted by the central government. Central government authorities argued that the nomenclature (IUPHHK-MHA) was not recognized by MOEF.

This leads to my second point about the rationale for rejecting this claim. The refusal of the central government, in which MOEF rejected such claims is baseless given that government policy of Tanah Papua is in line with Law no. 21 / 2001 concerning the Special Autonomy of Papua and Peraturan Daerah Khusus (the Special Regional Regulation) no. 21/ 2008 concerning Sustainable Forest Management in Papua. The initiative noted above, therefore, is actually an approach to responding to the incompatibility of regulations on forest management by customary communities in Papua issued by the central and local governments (Koalisi Anti Mafia Hutan, 2018). The central government, while on the one hand suggesting it supports forest devolution to customary communities, on the other hand their commitment to following up with these interests are thus half-hearted. For the Papuan people: "bicara hutan itu bicara adat dan manusia Papua. Tidak ada satu lahan hutan yang tak bertuan" (Talking about forest is necessarily talking about the customs and the people of Papua. Every inch of the forest are owned by someone) (Fatem, 2019).

Referring to the identification of sites listed in Peta Indikasi Areal Perhutanan Sosial (the Indicative Map of Social Forestry Areas) published by MOEF, Papua and West Papua are categorized as provinces that are envisioned to receive specific and accelerated support for social forestry. To respond to such initiatives to prepare for the indicative map, the West Papua province established task forces for social forestry by assisting stakeholders at different scales to formulate pre-conditions for designation. Setting the target for allocating social forestry areas in West Papua are significant, amounting to an identified land area of 254,581 hectares (SK.865/MenlhkPKTL/REN/PLA.0/9/2017). Meeting these targets in responsible ways that respond to the needs of local communities will obviously be a major undertaking for a multi-stakeholder group that involves numerous actors and institutions, including the local government, customary communities, universities, and other civil society organizations in the province. 


\section{Supporting social forestry programs on the basis of a conservation site}

To further contextualize social forestry reforms in Tanah Papua, several other local initiatives were also conducted in parallel. For instance, in 2012, the government of Tambrauw District proclaimed two development missions: the first establishes Tambrauw as a conservation district and the second, recognizes and protects the existence and interests of customary communities (Fatem and Asem, 2015; Fatem et al., 2018). This mission is also compatible with the broader policy development taking place in West Papua province. On October 19, 2015, following the example of Tambrauw, the government of West Papua province established itself as a conservation province. These macro-level guiding policies on establishing a conservation district and conservation province should indicate strong evidence to the public, especially highlighting to the central government that there is a compatibility of conservation policies between government levels that can at once support conservation and the recognition of customary communities.

The policies of establishing Tambrauw as a conservation district and West Papua, a conservation province, shape discourses on the necessary services given to, and provided by customary communities under the scheme of natural resource management. It means that the government at the district and central levels should ensure that customary communities gain access to natural resources for their well-being, and that such assurances to be able to thrive from natural resources is ensured through local-based practices in conservation zones (McNeely and Mainka, 2009). The perceived dichotomy between conservation-economy has long been an area of conflict in the history of conservation area management. Social forestry provides a viable opportunity to bridge these concepts and underlying priorities. Becoming a conservation district or conservation province, as a policy, is made locally, for the benefit of local people. In other words, such policies actually have not had a clear legal umbrella from the national level. However, the local government, therefore needs to translate the conservation policy so that it will bring real benefits to the local people. This presents a foundation for matching with the discursive ideas being promoted nationally through policies on social forestry.

The remaining challenge faced by a guiding policy as a conservation province or district however, still face the more challenging task of developing implementation arrangements in the form of policies, plans, and programs on the ground. The establishment of customary forests, village forests, or other social forestry schemes provide a real example for how implementation units in a conservation district and province can operationalize activities on the ground. Based on the Indicative Map of Social Forestry Area of the West Papua province, the Tambrauw District has allocated 12,403 hectares for social forestry. Working in partnership with non-governmental organizations, the local government has mapped out the customary areas and ethnic/tribal groups across these areas. There remain 3 tribal groups (Basakof, Tafi, and Wabia) who are in the process of gaining their ownership status over customary forests. Meanwhile, other social forestry schemes are in the identification process and undergoing mapping initiatives. Customary forests and other social forestry schemes in Tambrauw district will become precedent-setting examples of how a conservation district implements its conservation policies on the ground by recognizing the importance of working with local communities (Fatem, 2018). Social forestry schemes then become a strategic arena for collaboration, coordination and consultation among various parties.

The critical questions going forward therefore are as follows: to what extent will the social forestry scheme in Papua be designed by the central government? In what ways will social forestry schemes be implemented? And furthermore, how will success be determined in its implementation? 


\section{References}

Awang, S (Ed) (1999). Forest for People. Berbasis Ekosistem. Pustaka Hutan Rakyat. Yogyakarta. Brigraf Publishing.

Awang, S (2010). Kehutanan sosial berbasis reforma agraria.

Berkes, F., Colding, J., \& Folke, C. (2000). Rediscovery of traditional ecological knowledge as adaptive management. Ecological applications, 10(5), 1251-1262. doi:https://doi.org/10.1890/1051-0761(2000)010[1251:ROTEKA]2.0.CO;2

Berkes F. (2001). Religious Traditional and Biodiversity. Enclopedia of Biodiversity, 5:109-120

Direktorat Jenderal Rehabilitasi Lahan dan Perhutanan Sosial (2006). Statistik Kehutanan. 2006. Departemen Kehutanan, Jakarta.

Fisher, M. R., Moeliono, M., Mulyana, A., Yuliani, E. L., Adriadi, A., Judda, J., \& Sahide, M. A. K. (2018). Assessing the new social forestry project in Indonesia: recognition, livelihood and conservation?. International Forestry Review, 20(3), 346361.doi:https://doi.org/10.1505/146554818824063014.

Fatem, S. M., Awang, S. A., Pudyatmoko, S., Sahide, M. A., Pratama, A. A., \& Maryudi, A. (2018). Camouflaging economic development agendas with forest conservation narratives: $A$ strategy of lower governments for gaining authority in the re-centralising Indonesia. Land use policy, 78, 699-710. doi: https://doi.org/10.1016/j.landusepol.2018.07.018

Fatem, S. M., \& Asem, G. (2015). Kabupaten konservasi sebagai political action pemerintah daerah dalam mendukung konservasi sumberdaya alam hayati: Studi kasus Kabupaten Tambrauw, Papua Barat. Pros Sem Nas Masy Biodiv Indon, 1(6), 1403-1410.

Gilmour J.A and Fisher R.J. (1991). Villagers, forests, and foresters: The philosophy, process, and practice of community forestry in Nepal. Research Publication. Forestry Sciences. Sahayogi Press.

Koalisi Anti Mafia Hutan. (2018). Half Hearted Recognition. A study on Permit of Timber Utilisation by Indegnous Peoples in Papua. Jakarta. Indonesia.

Laksono, P.M. (2005). Igyaser Hanjop di Kawasan Pegunungan Arfak Papua. Pusat Studi Asia Pasifik Ugm Jogjakarta.

Mampioper, D.A. and C. Ayomi (2008). Masyarakat Adat dan Lunturnya Nilai adapt: Ironisnya seringkali mereka dituding perjuangkan aspirasi merdeka. Tabloit Jubi. Available at http://tabloidjubi.wordpress.com/2008/05/11/masyarakat-adat-danlunturnya-nilai-adat\%E2\%80\%9

Maryudi, A. (2012). Restoring state control over forest resources through administrative procedures: Evidence from a community forestry programme in Central Java, Indonesia. Aust. J. South-East Asian Stud. 5 (2), 229-242.

McNeely J.A, Mainka S.A. (2009). Conservation for a New Era. IUCN, Gland Switzerland.

Patay, M., Sasmitawidjaya, V.S. (2005). Peluang Yang Memperlemah Posisi Masyarakat Adat. Yayasan Kemala. World Resources Institute. World Wildlife Fund. Indonesia Programme. Region Sahul Papua.

Sahide, M. A. K., Fisher, M. R., Maryudi, A., Dhiaulhaq, A., Wulandari, C., Kim, Y. S., \& Giessen, L. (2018). Deadlock opportunism in contesting conservation areas in Indonesia. Land use policy, 77, 412-424.doi: https://doi.org/10.1016/j.landusepol.2018.05.020

Suharman. (2004). Konflik Pengelolaan Hutan Kemasyarakatan di Kawasan Gunung Kidul. Dalam Konflik dan Kekerasan pada Aras Lokal, editor Fera Nugroho, Pustaka Percik. Salatiga.

Sukadaryati. (2006). Potensi Hutan Rakyat di Indonesia dan Permasalahannya. Makalah Prosiding Seminar Hasil Litbang Hutan "Kontribusi Hutan Rakyat dalam Kesinambungan Industri Kehutanan". Pusat Penelitian dan Pengembangan Hasil Hutan, Bogor. 
Suryandari, E. Y . dan T. Puspitojati. (2003). Sistem Pengelolaan Hutan Rakyat ; Keragaman dan Kelestarian. Buletin Penelitian dan Pengembangan Kehutanan (4) 2

Wanggai F. (1999). Pemanfaatan Sumberdaya Alam Secara Rasional Dalam perspectife pemberdayaan masyarakat. Universitas Cenderawasih, Manokwari. 